Article

\title{
Removal Efficiencies of Constructed Wetland Planted with Phragmites and Vetiver in Treating Synthetic Wastewater Contaminated with High Concentration of PAHs
}

\author{
Rabia Alsghayer ${ }^{1}$, Ali Salmiaton ${ }^{1, *(1)}$, Thamer Mohammad ${ }^{2}$ (i), Azni Idris ${ }^{1}$ and \\ Che Fauziah Ishak ${ }^{3}$ \\ 1 Department of Chemical and Environmental Engineering, Faculty of Engineering, Universiti Putra Malaysia, \\ Serdang 43400, Selangor, Malaysia; alsagerr@yahoo.com (R.A.); azni@upm.edu.my (A.I.) \\ 2 Department of Water Resources Engineering, College of Engineering, University of Baghdad, Jaderiyah, Iraq; \\ tthamer@gmail.com \\ 3 Department of Land Management, Faculty of Agriculture, Universiti Putra Malaysia, Serdang 43400, \\ Malaysia; cfauziah@upm.edu.my \\ * Correspondence: mie@upm.edu.my; Tel.: +60-397696297
}

Received: 29 January 2020; Accepted: 4 March 2020; Published: 20 April 2020

check for updates

\begin{abstract}
This study aimed to evaluate the capability of horizontal subsurface flow constructed wetlands (HSFCWs) in treating contaminated wastewater with a high concentration of polycyclic aromatic hydrocarbons (PAHs) (Phenanthrene, Pyrene, and Benzo[a]Pyrene), using two plants, namely Phragmites and Vetiver. The investigated parameters were (1) PAHs uptake by the plants, (2) PAHs removal efficiencies, (3) accumulated PAHs in the soil of CWs, (4) shoot/root concentration factor, (5) translocation factor, and (6) PAHs correlation to lipid contains in the plants. During the treatment period, the results showed that the highest concentration of Phenanthrene in the shoot and the root systems of Phragmites, was 229.3 and192 $\mu \mathrm{g} / \mathrm{g}$; Pyrene was 69.1 and $59.2 \mu \mathrm{g} / \mathrm{g}$; and Benzo[a]Pyrene 25.1 and $20.2 \mu \mathrm{g} / \mathrm{g}$, respectively. Meanwhile, in the Vetiver shoot and root systems were Phenanthrene 87.5 and $64.1 \mu \mathrm{g} / \mathrm{g}$; Pyrene 63.2 and $42.1 \mu \mathrm{g} / \mathrm{g}$; and Benzo[a]Pyrene 21.3 and $27.3 \mu \mathrm{g} / \mathrm{g}$, respectively. The removal rates of Phenanthrene, Pyrene, and Benzo[a]Pyrene (PAHs compounds) by the CW planted with Phragmites were found to be $83 \%, 71 \%$, and $81 \%$, respectively, while the removal rates by CW planted with Vetiver were found to be $67 \%, 66 \%$, and $73 \%$, respectively. Moreover, the removal rates by unplanted CW were found to be $62 \%, 58 \%$, and $55 \%$, respectively. The results indicated that the HSFCW planted with Phragmites has an effective pathway to remove high concentrations of PAHs.
\end{abstract}

Keywords: constructed wetlands; plants; Phragmites; Vetiver; PAHs; phytoremediation; root and shoot content factors; removal rate

\section{Introduction}

The polycyclic aromatic hydrocarbons (PAHs) are major wastewater pollutants discharged mainly from petroleum refineries and petrochemical industries. Due to their benzene structures, PAHs compounds could cause several health hazards even at very low concentrations, while mutagenicity, carcinogenicity, and teratogenicity are on the top list of diseases caused by these pollutants $[1,2]$. Consequently, there is an increasing concern among the public regarding the environmental fate of PAHs. Thus, effective and safe remediation strategies are needed urgently in order to remove the PAHs from industrial wastewater. The new green technologies are alternative methods for wastewater treatment, which include the removal of toxic PAHs pollutants, such as 
phytoremediation in the constructed wetland [3,4]. Among the available processes, phytoremediation is one new cleanup concept that involves the use of plants to clean contaminated water [5]. Plants are an integral part of the wetland systems; furthermore, the literature highlighted its positive role in removing the contaminants through evolving interaction with water body, media, and microorganism [6-8]. The previous studies had also evaluated the removal efficiencies of PAHs and linear alkylbenzene sulfonates (LAS) by CWs. According to the studies, the average removals of PAHs and LAS were reported as $79.2 \%$ and $55.5 \%$ for constructed wetland, using subsurface flow (SSF); $68.2 \%$ and $30.0 \%$ for constructed wetland, using free water surface (FWS); and $73.3 \%$ and $40.9 \%$ for constructed wetland, using gravel filter [9].

In another research study, Rasmussen and Arnt [10] investigated the efficacy of removal of three-rings of PAHs from the soil using grass (Dactylis glomerata). It was found that effective removal of PAHs was dependent on the time of contact with the contaminated soil, and it demonstrated that biodegradation in the soil was stimulated by plants. Hence, the main mechanisms in the phytoremediation of organic contaminants are to (1) direct uptake of pollutants and their subsequent metabolism in plant tissues, (2) perfuse volatile organic hydrocarbons through the leaves, (3) release secretions that stimulate microbe activity, and (4) promote mineralization at the interface of the soil root, which is attributed to the microorganisms associated with the root surface [11,12].

Newman and Reynolds [13] found that metabolic transformations of different organic chemicals turned out to occur in a variety of plants, including constructed wetland plants such as the common reed (Phragmites australis), the broad-leaved cattail (Typha latifolia), and some common species (Populus sp.). In this research, a model scale of constructed wetlands planted with Phragmites and Vetiver was used to remove the three PAHs compounds, namely Phenanthrene (Phe), Pyrene (Pyr), and Benzo[a]Pyrene $(\mathrm{B}[\mathrm{a}] \mathrm{P})$, from synthetic industrial wastewater. Therefore, the novelty of the present study lies in the capability of horizontal subsurface flow constructed wetlands (HSFCWs) for removal of a high concentration of PAHs in the presence of two plants, namely Phragmites and Vetiver.

\section{Materials and Methods}

\subsection{Descriptions of Wetland Models}

A total of 20 pilots of horizontal subsurface flow constructed wetland system (HSFCWs) were fabricated at Universiti Putra, Malaysia, as shown in Figure 1. Eight of them were made of iron metal of $2 \mathrm{~mm}$ thickness coated with a plastic layer to prevent corrosion, and the dimensions of each one were $90 \mathrm{~cm} \times 30 \mathrm{~cm} \times 50 \mathrm{~cm}$ (length $\times$ width $\times$ depth). Both sides of the constructed wetlands were filled with coarse gravel $(\mathrm{d}=40-60 \mathrm{~mm})$ to a width of $5 \mathrm{~cm}$, to avoid clogging at the inlet and outlet, and then filled with $20 \mathrm{~cm}$ of height fine gravel $(\mathrm{d}=20-30 \mathrm{~mm})$ for the lowest layer and $15 \mathrm{~cm}$ of fine soil for the upper layer.

The prepared CWs for each plant were further divided into four categories of constructed wetlands, which consisted of three replicated and one control, where each one was transplanted with ten healthy plants of Phragmites and Vetiver (the age of each plant type is 3 months). Meanwhile, the other twelve constructed wetlands were smaller in size (length $=45 \mathrm{~cm}$, width $=15 \mathrm{~cm}$ and depth $=30 \mathrm{~cm}$ ) and were used to replace plants in CW after sampling, to avoid the effect of plant absence on treatment. Six of them were used to replace Phragmites plants, while the other six were used to replace Vetiver plants. The small CWs were filled with the same material used in the normal CWs. All plants were irrigated for 72 days, using artificial wastewater contaminated with a high concentration of PAHs $(10,000 \mu \mathrm{g} / \mathrm{L})$ and 2 days of hydraulic retention time. 

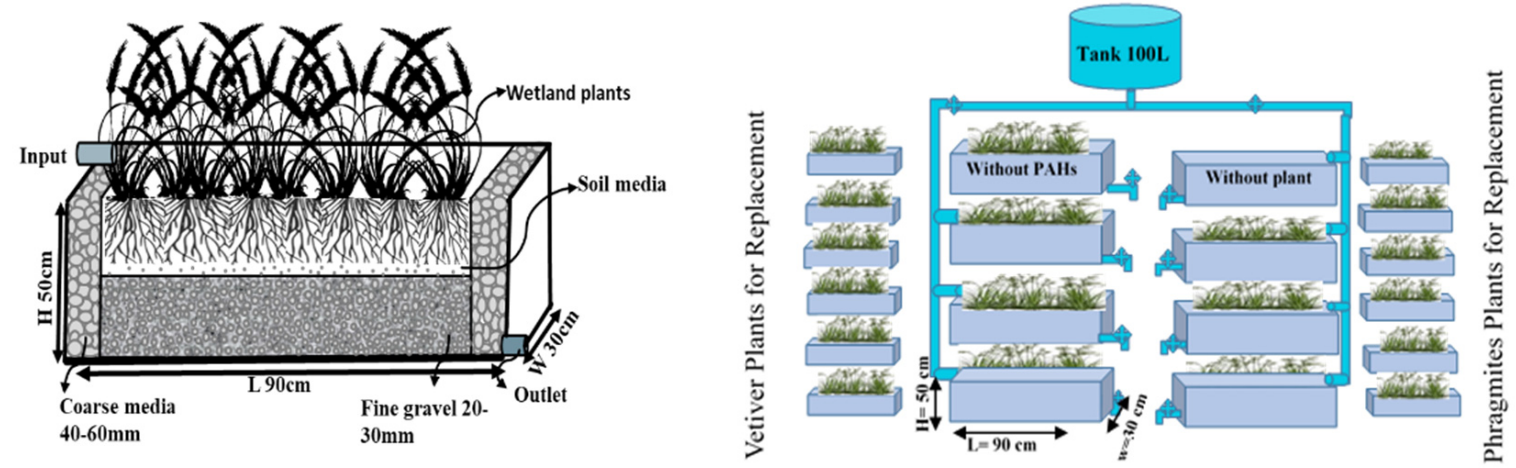

Figure 1. Schematic diagram of horizontal subsurface flow constructed wetland (HSFCWs).

\subsection{Preparation of Synthetic Wastewater}

In order to reflect the actual situation, synthetic wastewater was prepared by dissolving three compounds of PAHs, supplied by Sigma-Aldrich GmbH (Munich, Germany), in acetone and then mixed with distilled water. The selected compounds are typically found in PAHs and have different characteristics, as shown in Table 1 . The percentage of the three compounds of PAHs in the synthetic wastewater were $74.61 \%$ for Phenanthrene, $17.11 \%$ for Pyrene, and 8.28\% for Benzo[a]Pyrene, and they were prepared according to the earlier research studies $[14,15]$.

Table 1. Characteristics of synthetic wastewater used in the study.

\begin{tabular}{cccc}
\hline Compound Name & Phenanthrene & Pyrene & Benzo[a]Pyrene \\
\hline Compound abbreviation & Phe & Pyr & BaP \\
Benzene rings & 3 & 4 & 5 \\
Formula & $\mathrm{C} 14 \mathrm{H} 10$ & $\mathrm{C} 16 \mathrm{H} 12$ & $\mathrm{C} 20 \mathrm{H} 12$ \\
Water solubility $\left(\mathrm{mg} \cdot \mathrm{L}^{-1}\right.$ at $\left.25^{\circ} \mathrm{C}\right)$ & 1.18 & 0.12 & 0.0038 \\
Molecular weight $\left(\mathrm{gmol}^{-1}\right)$ & 178 & 202 & 252 \\
Boiling point $\left({ }^{\circ} \mathrm{C}\right)$ & $339-340$ & $360-404$ & $493-496$ \\
Kow & 4.46 & 4.88 & 6.35 \\
Purity of compounds $(\%)$ & 98 & 98 & $\geq 96$ \\
Chemical structure & &
\end{tabular}

\subsection{Plant Sampling and Analysis}

After the commencement of the experiments, as presented in Figure 2, plant samples were removed from the CWs on days 7, 14, 28, 42, and 72, for biomass measurement. The removed plants were replaced with plants cultivated under same conditions (same species, age, and irrigation water). After removal, the plants were thoroughly washed with tap water to remove attached sediments, rinsed with deionized water, and then dried, using absorbent paper [16]. Parts above ground and underground were manually separated. The height of the individual plant was recorded during the treatment period. The corresponding fractions were dried in an oven at $80^{\circ} \mathrm{C}$ for $48 \mathrm{~h}$, and the dry weights were recorded. 


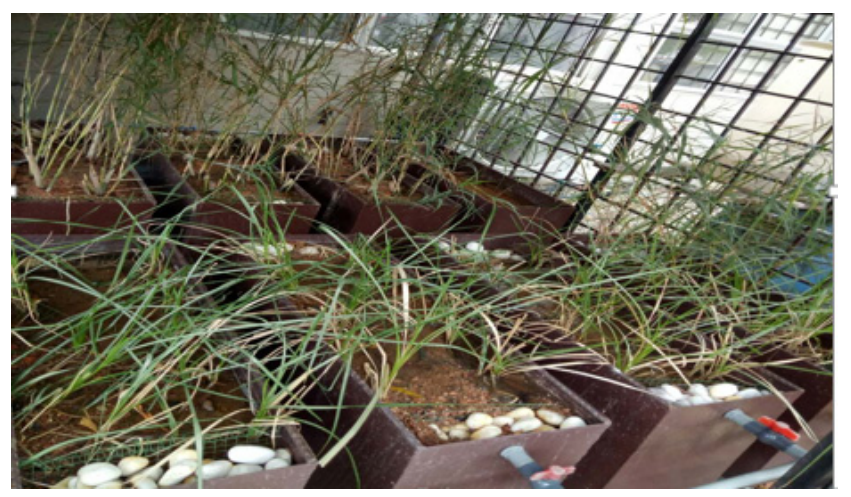

Figure 2. Experimental design of constructed wetlands with horizontal subsurface flow, planted with Phragmites and Vetiver.

\subsection{Relative Growth Rate}

The relative growth rate (RGR) was based on total dry biomass, and it was calculated by using Equation (1) [17].

$$
R G R=\frac{\left[\operatorname{In}\left(w_{2}\right)-\operatorname{In}\left(w_{1}\right)\right]}{\left(t_{2}-t_{1}\right)}
$$

where RGR is the relative growth rate (g/plant/day); $w_{1}$ and $w_{2}$ are the primary and final dry weights, respectively, for a complete plant sample; and $t_{1}$ and $t_{2}$ are the treatment times in days.

\subsection{PAHs Extraction}

Liquid-liquid extraction method was used to extract PAHs from wastewater [18]. The process involved $100 \mathrm{~mL}$ of wastewater sample extracted with $30 \mathrm{~mL}$ of dichloromethane, and then poured into a separator funnel. The mixture was shaken vigorously for two minutes before two-phase separation. The extract was combined, filtered, and dried with concentrated anhydrous sodium sulfate by rotary evaporation at $40{ }^{\circ} \mathrm{C}$. After removing the solvents, the residue obtained was dissolved in $2 \mathrm{~mL}$ of acetone and filtered through $0.45 \mathrm{~mm}$ polytetrafluoroethylene (PTFE) filters, and then injected for Gas Chromatography-Flame Ionization Detector (GC-FID) analysis.

The uptake of PAHs in plants was investigated by using the procedure as reported by previous research [19]. The samples of plants were dried at room temperature, before being grounded, homogenized, and sieved through a sieve No. $200 \mu \mathrm{m}$. Specifically, $1 \mathrm{~g}$ (dry weight) of the plant samples was extracted by ultra-sonication in 1:1 (v/v) resolution and mixed with dichloromethane and acetone. The solution was then decanted, collected, and replenished. The sample solution was sonicated for $1 \mathrm{~h}$, and the solution was decanted, collected, and replenished again. This exact procedure was repeated three times.

The soil samples were dried at room temperature, until they reached a constant weight and sieved with a $200 \mu \mathrm{m}$ sieve. The homogenized samples $(2.0 \mathrm{~g}$ each) were extracted by ultra-sonication in 1:1 (v/v) resolution, of mixed dichloromethane and acetone. The solution was then decanted, collected and replenished. The sample solution was sonicated for $1 \mathrm{~h}$, and the solution was decanted, collected, and replenished again. This procedure was also repeated for three times. The subsequent plant and soil samples concentration and cleansing procedures were similar as implemented for the wastewater samples.

\subsection{Analysis of PAHs by GC-FID}

The sample extracts $(2 \mu \mathrm{L})$ were analyzed by using Gas Chromatography (model Hewlett-Packard (HP) 6890), equipped with a HP5973 mass selective detector and a DB-5 capillary column (30 mm $\times 0.25 \mathrm{~mm} \times 0.25 \mathrm{~m}$ ). The separation was achieved according to the following program: the initial oven temperature was $80^{\circ} \mathrm{C}$ (held for one minute), and increased to $275{ }^{\circ} \mathrm{C}$ at $15^{\circ} \mathrm{C} / \mathrm{min}$, held for one 
minute; then to $285{ }^{\circ} \mathrm{C}$ at $10{ }^{\circ} \mathrm{C} / \mathrm{min}$, held for one minute; and then increased to $295{ }^{\circ} \mathrm{C}$ at $5{ }^{\circ} \mathrm{C} / \mathrm{min}$, held for one minute. During the process, nitrogen was used as a carrier gas $(1.5 \mathrm{~mL} / \mathrm{min})$ and makeup gas $(35 \mathrm{~mL} / \mathrm{min})$. A $1.0 \mathrm{~L}$ aliquot of the extract was injected into the splitless mode. The injector was held at $250{ }^{\circ} \mathrm{C}$ and the detector at $300{ }^{\circ} \mathrm{C}$ [20].

\section{Results and Discussion}

\subsection{Plants Growth with PAHs Contaminant}

The plant's height is a general criterion indicating plant growth and also an important trait which reflects their growth and adaptive characteristics. The result of plant height in the constructed wetlands is illustrated in Figure 3. Plant height increased with the increased retention time, resulting in positive growth rates reflecting the ability of Phragmites and Vetiver to tolerate contaminated effluent with PAHs. For the period of the experiments, the heights of Phragmites and Vetiver were ranged from 129 to $143 \mathrm{~cm}$ and from 87 to $119 \mathrm{~cm}$, respectively. Significant differences in heights between the two communities were found for both plants; $F(287,83)=287.076 ; p=0.005 ;$ Wilks' $\Lambda=0.126$.

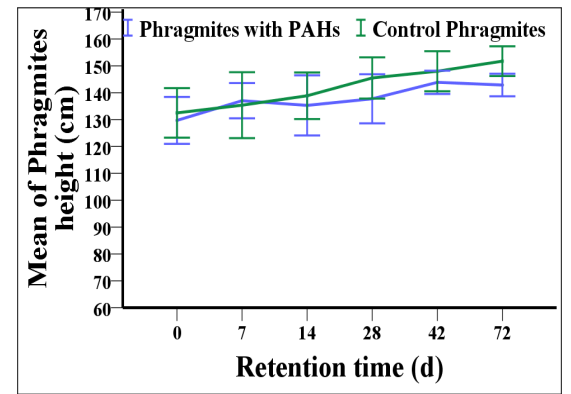

(a)

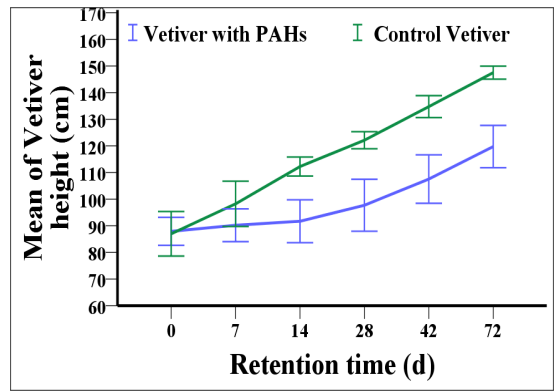

(b)

Figure 3. Mean plants height of plants growing in high concentration $(10,000 \mu \mathrm{g} / \mathrm{L})$ of PAHs in CW at different retention times compare to control plant: (a) Phragmites with and control plant and (b) Vetiver with control plant.

Based on the comparison between Phragmites and Vetiver plants grown in the CWs, it was found that the height of the Phragmites at the beginning was higher than Vetiver. The increase in the Vetiver height ratio was higher than Phragmites (44\% and 19\%). A comparison which was made for each plant with control plant of the same type had revealed that the growth trend is very close and the difference between the Phragmites and Vetiver is due to the different morphology of each plant. A similar trend was observed by other researchers as well [21,22]. An increase in plant height can lead to the presence of large amounts of biomass, which correspond to the significant removal of PAHs from liquid waste. Continuous increment in plant height of the CW indicates the ability of the plant species for shoot elongation and production of larger biomass.

Biomass response varied considerably among species. In this study, significant differences were observed between the two types of wetland plants in the biomass of shoots and root systems, and the magnitudes of the differences, were increased with increasing retention time, as shown in Figure 4. Meanwhile, the largest dry weights of the shoot and root systems of Phragmites were ranged from 28.7 to 45.1 and 18.1 to $27.5 \mathrm{~g} / \mathrm{plant}$, respectively. The dry biomasses of Vetiver shoot and root systems ranged from 15.3 to 18.1 and 9.6 to $12.3 \mathrm{~g} /$ plant, respectively. Meanwhile the comparison between shoot and root biomass to control plant observed low biomass in two parts of the plants during retention time. Perhaps this was caused by the toxic contaminants restrain on the proliferation of plant roots, its vitality, and microbes in the rhizosphere [23]. Moreover, a 4\% decrease in root biomass was seen in the root of F. arundinacea after mixing the PAH treatment [24]. Gao et al. [25] reported that PAH degradation was enhanced at the early stage and decreased as root exudates depleted. 


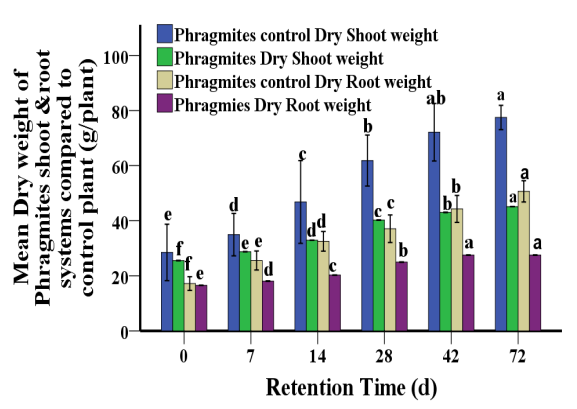

(a)

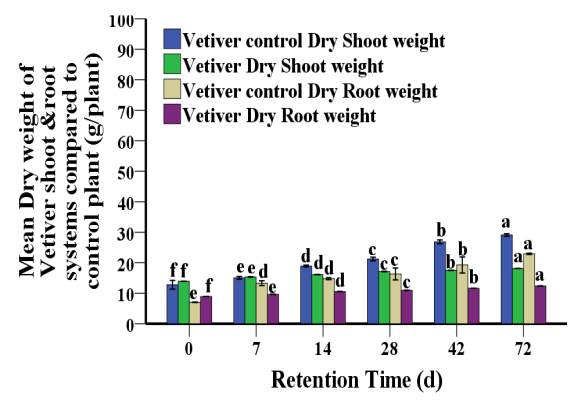

(b)

Figure 4. Total dry biomass of different parts of Phragmites and Vetiver during 72 days exposure to PAHs concentration (10,000 $\mu \mathrm{g} / \mathrm{L}$ ). (a) Dry biomass of Shoot and Root system of Phragmites, and (b) Dry biomass of Shoot and Root system of Vetiver. Note: Letters $a, b$, and c indicate significant difference among dry weight of different parts of the plant during the retention time at $5 \%$ level of Tukey $(p \leq 0.05)$.

The variation in morphology of Phragmites and Vetiver led to a distinct difference in the biomass of these plants, where the Phragmites was reported to be three times greater than Vetiver. Moreover, a clear difference could also be found between the biomass of both plants used in the treatment of PAHs with high concentrations and the biomass of control plant. The possible reasons for the low biomass growth ratio of the two plants compared to control plants are due to the effect of the high concentration of PAHs. Wang et al. [23] found that, when exposed to higher concentrations of diesel, reed plants would inhibit the synthesis of chlorophyll, thus reducing chlorophyll content in plants, as well as photosynthesis and inhibiting plant growth.

Based on the findings, it can be concluded that Phragmites and Vetiver plants were more tolerant to high concentration of PAHs $10,000 \mu \mathrm{g} / \mathrm{L}$, as the biomass of the plants continued to increase during the retention time, albeit in small proportions of Phragmites and Vetiver plants, which may possess traits that enable them to cope with oxygen limitation in the root zone and also under unfavorable biochemical reduction processes. Additionally, interactions between the plant genotype and microorganism may cause significant differences in plant growth, for example, the effect on root morphology and microbial activity. These interactions may have positive or negative effects on the use of plant nutrients and metabolism [26]. Genes related to the degradation of hydrocarbons were generally expressed in the root zone contaminated with PAH compared to bulk soil, which could help to improve microorganisms associated with plant treatment systems [27].

The relative growth rate (RGR) of plants is a major component of fitness. In theory, the RGR of plants would be closely related to biomass allocation. The (RGR) of the shoot and root system of Phragmites and Vetiver in a constructed wetland for treating PAHs with high concentrations $(10,000 \mu \mathrm{g} / \mathrm{L})$ is shown in Figure 5 . The results show that the RGR of both plants were affected by the high concentration of PAHs, where the RGR of both plants exhibited a lower outcome, which did not exceed $0.02 \mathrm{~g}$. Phragmites shoot and root system reached the highest relative growth rate $(0.019$ and $0.016 \mathrm{~g} / \mathrm{d}$ ) at 14 days, and then gradually began to decrease toward the end of the treatment period. Andreolli et al. [28] observed a decrease in biomass, stem length, and dry root weight of PAH-treated plants when compared to the untreated ones. On the other hand, the RGR of Vetiver in the shoot and root systems was significantly lower than in the control plant, with the highest growth rate of the shoot system at seven days with $0.014 \mathrm{gd}^{-1}$ and the highest growth rate in the root system at 14 days with $0.013 \mathrm{~g} / \mathrm{d}$. 


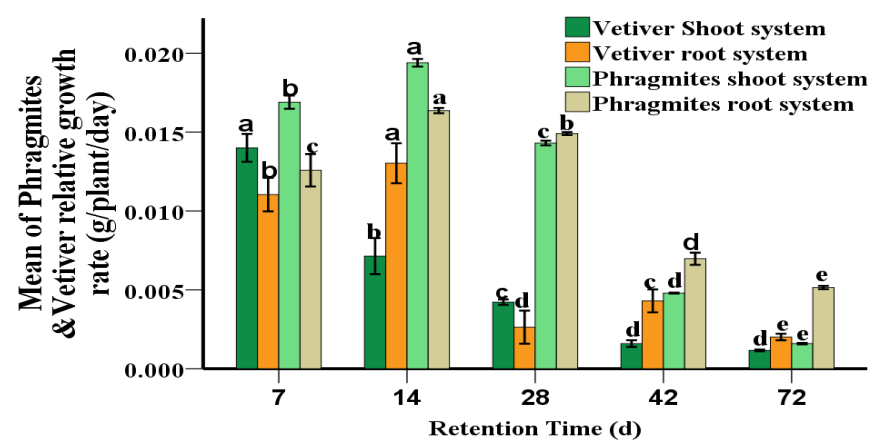

Figure 5. Relative growth rate (RGR) of Phragmites and Vetiver in constructed wetlands influenced by three compound of PAHs during 72 days of treatment period. Note: Letters $a, b$, and c indicate significant difference among relative growth rate of different parts of the plant during the retention time at $5 \%$ level of Tukey $(p \leq 0.05)$.

\subsection{Concentration of PAHs in Phragmites and Vetiver Plant Species}

The concentrations of the three compounds of PAHs in the selected plant species are presented in Figure 6. It was found that the concentrations in both plants had increased, and after a certain time, it started to decrease. The highest concentration of total Phenanthrene was obtained in the shoot system of Phragmites (Figure 6a), with an average value of $229.3 \mu \mathrm{g} / \mathrm{g}$, and was in the root of the same plant with $192 \mu \mathrm{g} / \mathrm{g}$. Meanwhile the highest concentration of Phenanthrene in the shoots and roots system of Vetiver (Figure 6b) was 87.5 and $64.1 \mu \mathrm{g} / \mathrm{g}$, respectively.

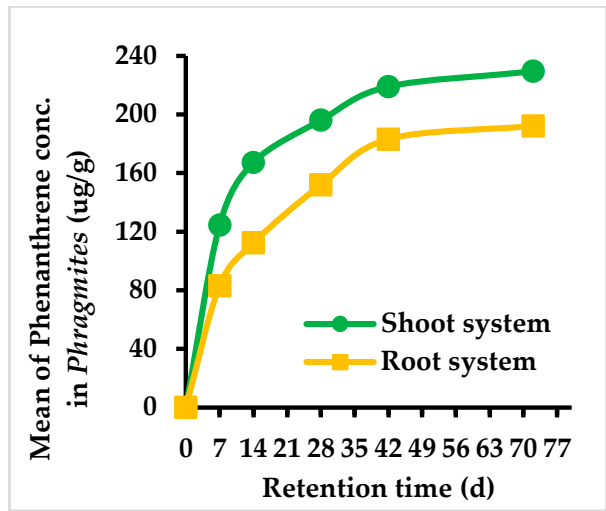

(a)

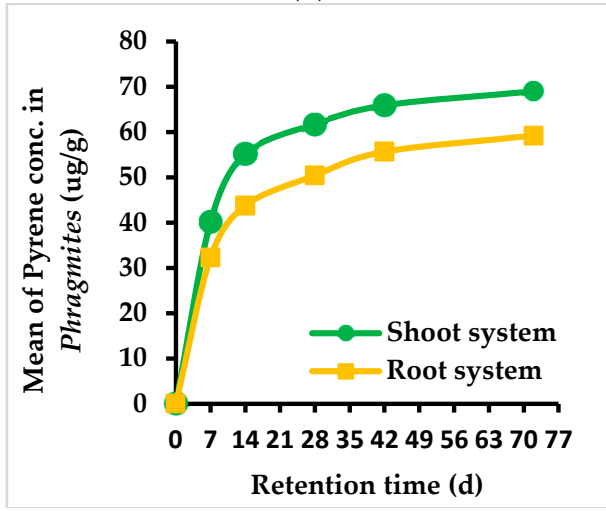

(c)

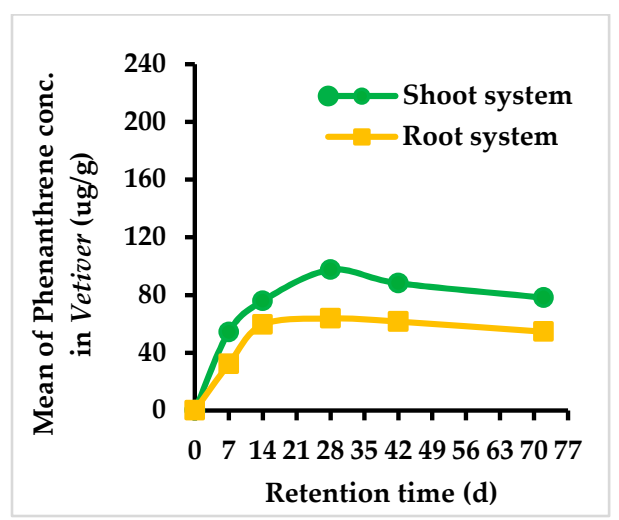

(b)

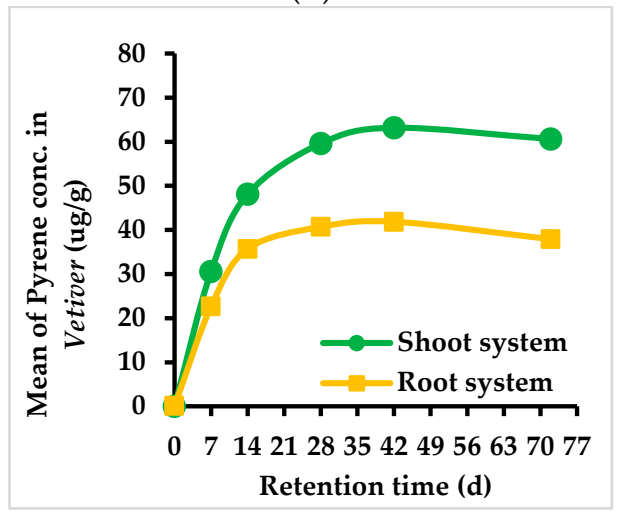

(d)

Figure 6. Cont. 


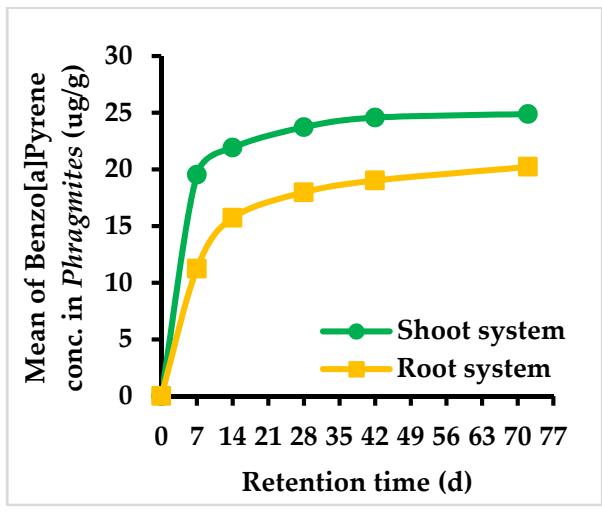

(e)

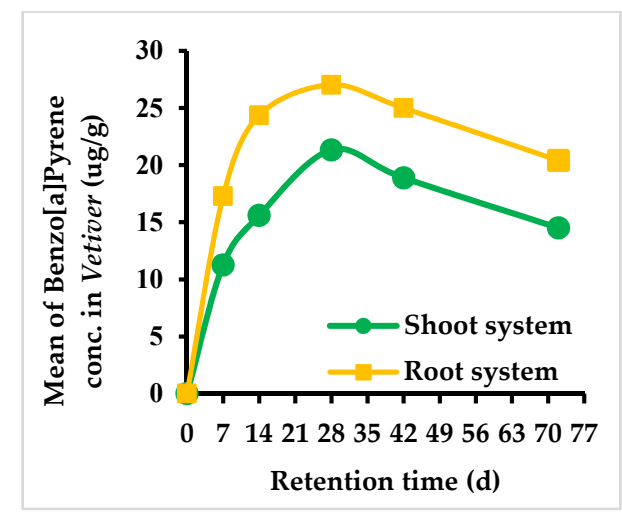

(f)

Figure 6. Mean concentration values of three compounds of PAHs (a) Phenanthrene concentration by Phragmites, (b) Phenanthrene concentration by Vetiver, (c) Pyrene concentration by Phragmites, (d) Pyrene concentration by Vetiver, (e) Benzo[a] Pyrene concentration by Phragmites, and (f) Benzo[a] Pyrene concentration by Vetiver.

The concentration of the four-rings Pyrene of PAHs for different plant species' parts over time of treatment is presented in Figure 6c,d. The highest concentration of Pyrene in Phragmites (Figure 6c) shoot system was recorded at $69.1 \mu \mathrm{g} / \mathrm{g}$ and was at the same level as in roots $59.2 \mu \mathrm{g} / \mathrm{g}$. Meanwhile, the highest Pyrene concentration in Vetiver (Figure 6d) shoot system was recorded at 63.2 and $42.1 \mu \mathrm{g} / \mathrm{g}$ in root.

The concentration of five hydrocarbons in the shoot system of Phragmites (Figure 6e) was $25.1 \mu \mathrm{g} / \mathrm{g}$ which was higher than the root system at $20.2 \mu \mathrm{g} / \mathrm{g}$. In contrast, the concentration of B[a]P in the Vetiver (Figure 6f) shoot system was $21.3 \mu \mathrm{g} / \mathrm{g}$ and is lower than the root system of the same plant recorded at $27.3 \mu \mathrm{g} / \mathrm{g}$. Sun and Zhou [29] also found that concentrations of B[a]P in the roots of two plants were higher than those in the aerial parts (stems, leaves, and shoots). Several studies demonstrated that the plants have a high ability to uptake Phenanthrene than Pyrene and B[a]P [29,30].

The characteristics of Phe compound, such as low molecular weight, high solubility in most low-polar organic solvents, and high presence in synthetic wastewater in constructed wetlands, enable the uptake and degradation of these compounds in larger quantities. The Phragmites plants have high uptake ability compared to the Vetiver plants, due to the presence of strong rhizosphere. Binet et al. [31] found that phytoremediation of PAHs depends on the beneficial effects of plant rhizosphere on their dissipation. Under the influence of roots, the bioavailability of organic compounds can be increased in the soil of the rhizosphere through the activation of organic compounds derived from root secretions and the degradation of soil organic matter. Thus, these active organic chemicals can be absorbed by plant roots and transported to the top of the shoots [32]. However, it is difficult to compare the PAHs uptake of this study to other studies because most of the results obtained involved the PAHs uptake from media such as (soil/water), which has a low contamination rate, for example, the initial concentration of Pyrene was $200 \mathrm{mg} / \mathrm{kg}$ [33]; the sum of 16 PAHs in the influent was $786 \pm 514 \mathrm{ng} / \mathrm{L}$ [9]; the average PAHs content of the raw sludge measured was $5.69 \mathrm{mg} / \mathrm{kg}$ [13], and the initial Phenanthrene concentration was $200 \mathrm{mg} / \mathrm{kg}$ [34].

The results of this study confirm that the ability of plants used in CW to absorb PAHs is highly depending on the PAHs concentration in the media in which the plants grow and also retention time $[35,36]$. For examples, the total concentration of 16 PAHs varied between 32 and $42 \mu \mathrm{g} / \mathrm{kg}$ d.m , and the accumulation of USEPA categorized 16 PAHs, which were examined in different parts of Glyceria maxima plants, and observed that PAHs in root, leaves, and stems were 85,143 , and $92 \mu \mathrm{g} / \mathrm{kg}_{\mathrm{d} . \mathrm{m}}$, respectively [36]. According to Sieciechowicz et al. [37], they found that the average content of 15 PAHs in the soil did not exceeded $700 \mu \mathrm{g} / \mathrm{kg}_{\mathrm{d} . \mathrm{m}}$, while the range in the leaves was $112-118 \mu \mathrm{g} / \mathrm{kg}$ d.m, which was found, on average, to be twice as high as that in stems, at $49-59 \mu \mathrm{g} / \mathrm{kg}$ d.m , and roots, at $65-69$ $\mu \mathrm{g} / \mathrm{kg}_{\mathrm{d} . \mathrm{m}}$. Plants may metabolize hydrocarbons in the common metabolic destinies, as well as reactive 
products that may accumulate in tissues, e.g., roots. Predestination is possible if hydrocarbons are available in roots and migrate across the stem [36,38,39].

\subsection{Assessment of PAH Removal Efficacy}

The removal of three PAHs compounds from three CW systems is presented in Figure 7. The results clearly indicate that the removal rates of PAHs decreased with an increase in time in all CW systems. The results suggested that the removal degradation efficiencies were better and faster in CWs with plants.

The level of removal of phenanthrene in CWs planted with Phragmites ranged up to $91 \%$ at the beginning of treatment, and then it declined slowly, to $83 \%$, by the end of treatment. The average removal efficiency of Phenanthrene in CW planted with Vetiver ranged from the first retention time to the end of treatment between $80 \%$ and $67 \%$. Meanwhile, unplanted systems reached the removal efficiency for Phenanthrene between $76 \%$ and $62 \%$, which was the lowest removal efficiency when compared to other systems. Ansari [40] found that, in the case of soil planted with B. juncea, Phenanthrene showed the highest degradations, at $88 \%$, when compared to other PAH compounds, and most PAH degradation rates increased by $20-40 \%$, compared to those in uncultivated soil.

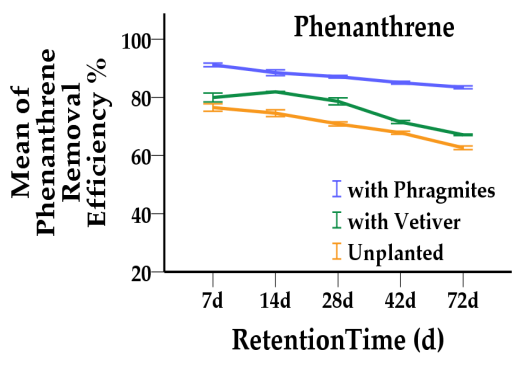

(a)

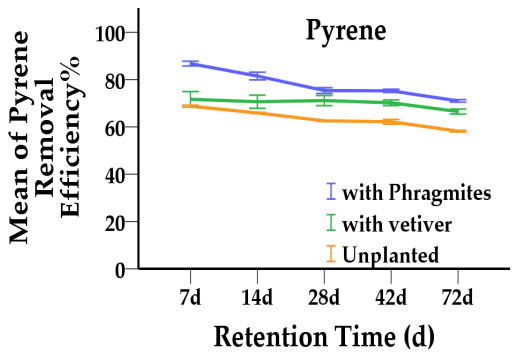

(b)

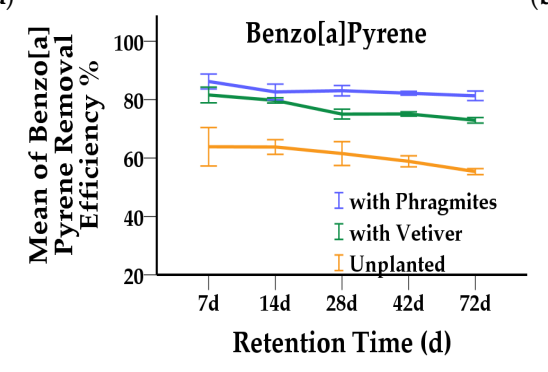

(c)

Figure 7. Mean values of removal percentage for three compounds of PAHs contaminated wastewater in constructed wetlands in the presence of Phragmites, Vetiver, and without plants. (a) Phenanthrene removal efficiency, (b) Pyrene removal efficiency, and (c) Benzo[a] Pyrene removal efficiency.

The Pyrene removal capacity of CWs planted with Phragmites, Vetiver, and unplanted system ranged from $87 \%$ to $71 \%, 72 \%$ to $66 \%$, and $69 \%$ to $58 \%$, respectively, with a significant difference $(p<0.05)$ between sampling days 7 and 72 . The four-rings PAHs had low removal rates and proved to be more difficult to biodegrade than the three-ring PAHs. For this reason, the three-ring PAHs were preferred for the removal process, as indicated by Braeckevelt et al. [41]. The removal percentages of Benzo[a]Pyrene in CW with planted with Phragmites, Vetiver, and unplanted were $81-86 \%$, 73-80\%, and 55-64\% respectively. The differences in reduction of PAHs between with and without plant were statistically significant $(p<0.05)$.

Based on the results, it was observed that lower PAHs removal was found in unplanted CWs as compared to planted CWs. This indicated that the presence of plants can facilitate the removal of PAHs from unplanted $\mathrm{CW}$, which contained more roots, shoot biomass, and microorganisms that had boosted the treatment efficiency and believed to occur through a rhizosphere effect [42]. Furthermore, the flow 
in the SSF system is horizontal through the upheld media and includes aerobic, anoxic, and anaerobic zones. The aerobic zone is located around the roots that provide oxygen to the substrate zone [43].

Fountoulakis et al. [9] recorded that the average efficiency of PAHs removal was $79.2 \%, 68.2 \%$, and $73.3 \%$ for SSF, FWS, and GF, respectively. Terzakis et al. [44] examined two FWS and two SSF pilot-size constructed wetlands treating highway runoff and found a comprehensive removal of $16 \mathrm{PAHs}$ of 59\%. Machate et al. [45] studied synthetic wastewater containing Phenanthrene, which was treated in the horizontal-ertical flow macrophytic-based treatment system and showed a $99.9 \%$ removal ratio.

Generally, treatments with different plant species will display different dissipation ratios. In this study, the performance of constructed wetland was clearly better with Phragmites. Fraser et al. [46] observed that Phragmites has a resilient rhizome system with high propagation ability, long growth period, strong adaptability, and strong resistance to pollution. This result is consistent with the findings obtained by Huang et al.'s study [47] in which they reported an improvement in the removal efficiency of $\mathrm{Cu}, \mathrm{Zn}, \mathrm{Pb}$, and $\mathrm{Cr}$ compounds existing in the treated wastewater. Ballesteros et al. [48] concluded from their investigation that the CW system planted with Phragmites Kaka exhibited excellent and nearly complete removals, at an influent concentration level of $45 \mathrm{mg} / \mathrm{L}$, suggesting that toxic and inhibitory effects depend on the system and that these effects were absent for this particular system at this contaminant level.

\subsection{Accumulation of PAHs in the Soil of Constructed Wetland}

Stabilization and adsorption onto substrates are considered to be the most potential removal processes for PAHs. The accumulation of Phenanthrene, Pyrene, and Benzo[a]Pyrene in the CWs soil is shown in Figure 8. Phenanthrene recorded the highest accumulated concentration in the soil, compared to other compounds, owing to the highest ratio in the influent concentrations. Same trend was observed by Zhang et al. [49]. As observed, the accumulation of Phe in two planted CWs was significantly less than unplanted CWs, giving Phragmites 2.9-12.4 $\mu \mathrm{g} / \mathrm{g}$, Vetiver 3.7-16.9 $\mu \mathrm{g} / \mathrm{g}$, and unplanted system $5.5-19.5 \mu \mathrm{g} / \mathrm{g}$. Plant roots provide readily degradable carbon, which is energy that generally increases microbial activity in the soil, which may lead to further degradation of organic pollutants through direct metabolism or a combined metabolism [50,51].

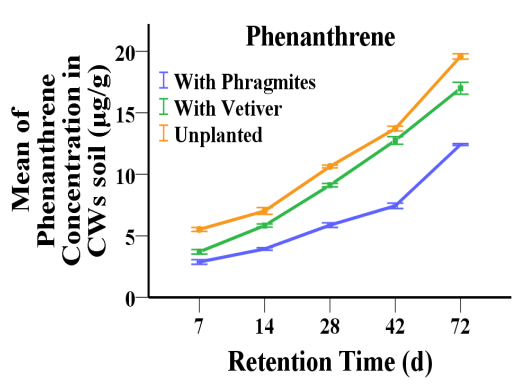

(a)

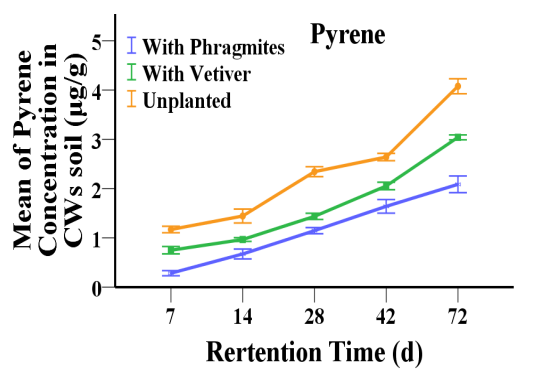

(b)

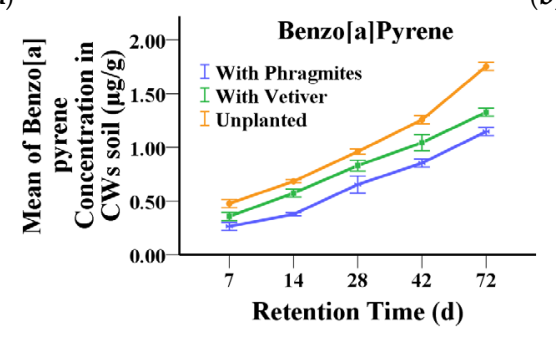

(c)

Figure 8. Mean concentration of three compounds of PAHs in constructed wetlands soil in the presence of Phragmites, Vetiver, and without plants: (a) Phenanthrene, (b) Pyrene, and (c) Benzo[a]Pyrene.

The accumulation of Pyrene in soils, especially in unplanted CW from 1.4 to $4.7 \mu \mathrm{g} / \mathrm{g}$ significantly increased with increment time of treatment. Meanwhile the low accumulation was observed in CW 
soil planted with Phragmites during the retention time, which ranged from 0.3 to $2.1 \mu \mathrm{g} / \mathrm{g}$, as compared to the Pyrene concentration in the CW soil planted with Vetiver at $0.8-3.1 \mu \mathrm{g} / \mathrm{g}$. The Pyrene was more persistent in unplanted CW soils than planted CWs, due to the presence of plants that improve the soil structure and thus ventilation and hydrological properties.

A similar trend was observed for accumulation of $\mathrm{B}[\mathrm{a}] \mathrm{P}$ in the unplanted CWs soil, which ranged from 0.47 to $1.02 \mu \mathrm{g} / \mathrm{g}$ which was significantly greater than the B[a]P in the CWs soil planted with Phragmites $(0.26-0.65 \mu \mathrm{g} / \mathrm{g})$ and accumulation of B[a]P in CWs soil planted with Vetiver $(0.35-0.82 \mu \mathrm{g} / \mathrm{g})$. The remediation for $\mathrm{B}[\mathrm{a}] \mathrm{P}$ required long periods of degradation due to its less water solubility and the difficulty in controlling the conditions, thus preventing degradation [52].

It is worth noting that, in light of the corresponding experiences, there was a significant difference between the concentrations of the three PAHs compounds in the soils of both unplanted CWs and planted CWs with Phragmites and Vetiver. The different accumulation between the three compounds of PAHs in CWs soil was probably related to different initial concentrations of these compounds, which have been identified depending on their presence in industrial wastewater, and due to the different characteristics of each compound. The low molecular weight of Phe could increase its movement under saturated conditions in the CWs, considering that water solubility is an important factor influencing PAH mobility in CWs [53]. Meanwhile, Pyr and B[a]P with four and five rings were prevalent in the particle stage and can generally be deposited in increasing proportions [54]. According to Gao and Zhu [55] and Huesemann et al. [11], the accumulated PAHs in soils that contain high octanol-water partition coefficients $\left(\mathrm{K}_{\mathrm{ow}}\right)$ can be related to the soil organic matter, which makes it not readily available for uptake by the root. The increased dissipation of PAHs in planted CWs versus unplanted CWs soils can be attributed to plant uptake and plant biodegradation. Cottin et al. [56] found that the organic matter accumulated on the top of aged VFCW had a great adsorption capacity and could degrade PAHs with slow biodegradation kinetics.

\subsection{Bioconcentration Factor and Translocation Ability of PAHs}

Plants' uptake of Phe, Pyr, and B[a]P were evaluated by calculating SCF and RCF [57], as presented in Tables 2 and 3. In this study, the SCF and RCF ranged from 0.02 to 0.03 and 0.01 to 0.03 for Phe in the Phragmites, while in Vetiver, they ranged from 0.01 to 0.01 and 0.00 to 0.01 , respectively, suggesting that accumulation of Phe in Phragmites was greater than those observed in Vetiver and SCF was higher than RCF. The high SCF values may be due to relatively lower molecular weight and higher water solubility of Phe.

Pyrene varied significantly among different plant species. The range of SCF and RCF for Pyrene in Phragmites were found to be $0.02-0.04$ and $0.02-0.04$, respectively, while in Vetiver, their ranges were found to be $0.02-0.04$ and $0.01-0.02$, respectively. Based on the results shown in Tables 2 and 3, the SCF and RCF of the Phragmites had recorded high values of Pyrene when compared to Vetiver. The higher values in Phragmites may be due to plant ability. Cui et al. [13] found that P. Australis accumulated PAHs effectively compared with native plants, and the contents of middle-MW and high-MW PAHs in leaves were much higher than those in roots and stems.

The SCF and RCF of the B[a]P were the highest in the Vetiver plants, ranging from 0.04 to 0.05 and 0.06 to 0.07 , while the lowest values were in the Phragmites plants, ranging from 0.02 to 0.03 and 0.01 to 0.02 , respectively. The Vetiver was characterized by a higher ability to accumulate the B[a]P than Phragmites; therefore, the RCF of the Vetiver was higher compared to SCF. The same trend was observed in the study by Sivaram et al. [58], which found that the SCF and RCF of Benzo[a]Pyrene in Vetiver were 0.002 and 0.08 , respectively. Sun et al. [29] likewise recorded the concentrations of B[a]P in the roots of two plants, where they were found to be greater than those in aerial parts. 
Table 2. Concentrations of PAHs in Phragmites tissues, shoot and root concentration factors (SCFs and RCFs), and the root-to-shoot transfer factors (TFs) at high condition of treatment $(10,000 \mu \mathrm{g} / \mathrm{L}$ ). Values (means $\pm \mathrm{SE}$ ) followed by the same letter within columns are not significantly different according to the least significant difference test $(p<0.05)$.

\begin{tabular}{|c|c|c|c|c|c|c|c|c|c|}
\hline \multirow{2}{*}{$\begin{array}{l}\text { Time } \\
\text { (d) }\end{array}$} & \multicolumn{3}{|c|}{ Phenanthrene } & \multicolumn{3}{|c|}{ Pyrene } & \multicolumn{3}{|c|}{ Benzo[a]Pyrene } \\
\hline & SCF & RCF & TF $\%$ & SCF & RCF & TF $\%$ & SCF & RCF & TF $\%$ \\
\hline 7 & $0.02 \pm 0.00^{\mathrm{e}}$ & $0.01 \pm 0.00^{\mathrm{e}}$ & $1.50 \pm 0.02^{a}$ & $0.02 \pm 0.00^{\mathrm{e}}$ & $0.02 \pm 0.01^{\mathrm{e}}$ & $1.25 \pm 0.03^{a}$ & $0.02 \pm 0.00^{c}$ & $0.01 \pm 0.00^{d}$ & $1.73 \pm 0.03^{a}$ \\
\hline 14 & $0.02 \pm 0.00^{\mathrm{d}}$ & $0.02 \pm 0.00^{\mathrm{d}}$ & $1.48 \pm 0.01^{\mathrm{a}}$ & $0.03 \pm 0.00^{\mathrm{d}}$ & $0.03 \pm 0.01^{\mathrm{d}}$ & $1.26 \pm 0.03^{a}$ & $0.03 \pm 0.00^{b}$ & $0.02 \pm 0.00^{c}$ & $1.39 \pm 0.03^{b}$ \\
\hline 28 & $0.03 \pm 0.00^{c}$ & $0.02 \pm 0.00^{c}$ & $1.29 \pm 0.01^{b}$ & $0.04 \pm 0.00^{c}$ & $0.03 \pm 0.01^{\mathrm{c}}$ & $1.22 \pm 0.03^{\mathrm{a}}$ & $0.03 \pm 0.00^{\mathrm{a}}$ & $0.02 \pm 0.00^{b}$ & $1.32 \pm 0.03 b c$ \\
\hline 42 & $0.03 \pm 0.00^{b}$ & $0.03 \pm 0.00^{b}$ & $1.19 \pm 0.01^{c}$ & $0.04 \pm 0.00^{b}$ & $0.03 \pm 0.01^{b}$ & $1.18 \pm 0.03^{a}$ & $0.03 \pm 0.00^{a}$ & $0.02 \pm 0.00^{b}$ & $1.29 \pm 0.03^{b c}$ \\
\hline 72 & $0.03 \pm 0.00^{\mathrm{a}}$ & $0.03 \pm 0.00^{\mathrm{a}}$ & $1.19 \pm 0.01^{\mathrm{c}}$ & $0.04 \pm 0.00^{a}$ & $0.04 \pm 0.01^{\mathrm{a}}$ & $1.16 \pm 0.03^{a}$ & $0.03 \pm 0.00^{\mathrm{a}}$ & $0.02 \pm 0.00^{a}$ & $1.23 \pm 0.03^{b}$ \\
\hline
\end{tabular}

Table 3. Concentrations of PAHs in Vetiver tissues, shoot and root concentration factors (SCFs and RCFs), and the root-to-shoot transfer factors (TFs) at high condition of treatment $(10,000 \mu \mathrm{g} / \mathrm{L})$. Values (means $\pm \mathrm{SE}$ ) followed by the same letter within columns are not significantly different, according to the least significant difference test $(p<0.05)$.

\begin{tabular}{|c|c|c|c|c|c|c|c|c|c|}
\hline \multirow{2}{*}{$\begin{array}{l}\text { Time } \\
\text { (d) }\end{array}$} & \multicolumn{3}{|c|}{ Phenanthrene } & \multicolumn{3}{|c|}{ Pyrene } & \multicolumn{3}{|c|}{ Benzo[a]Pyrene } \\
\hline & SCF & RCF & TF \% & SCF & RCF & TF \% & SCF & RCF & TF \% \\
\hline 7 & $0.01 \pm 0.00^{c}$ & $0.00 \pm 0.00^{c}$ & $1.70 \pm 0.04^{\mathrm{a}}$ & $0.02 \pm 0.01^{d}$ & $0.01 \pm 0.00^{\mathrm{d}}$ & $1.35 \pm 0.01^{\mathrm{c}}$ & $0.04 \pm 0.00^{d}$ & $0.06 \pm 0.00^{d}$ & $0.65 \pm 0.01^{\mathrm{cd}}$ \\
\hline 14 & $0.01 \pm 0.00^{b}$ & $0.01 \pm 0.00^{\mathrm{a}}$ & $1.28 \pm 0.04^{b}$ & $0.03 \pm 0.01^{b}$ & $0.02 \pm 0.00^{c}$ & $1.35 \pm 0.01^{\mathrm{c}}$ & $0.06 \pm 0.00^{c}$ & $0.09 \pm 0.00^{b}$ & $0.64 \pm 0.01^{d}$ \\
\hline 28 & $0.01 \pm 0.00^{\mathrm{a}}$ & $0.01 \pm 0.00^{\mathrm{a}}$ & $1.37 \pm 0.04^{b}$ & $0.03 \pm 0.01 \mathrm{~b}$ & $0.02 \pm 0.00 \mathrm{ab}$ & $1.46 \pm 0.01^{b}$ & $0.08 \pm 0.00^{\mathrm{a}}$ & $0.10 \pm 0.00^{\mathrm{a}}$ & $0.79 \pm 0.01^{\mathrm{a}}$ \\
\hline 42 & $0.01 \pm 0.00^{\mathrm{a}}$ & $0.01 \pm 0.00^{\mathrm{a}}$ & $1.35 \pm 0.04^{b}$ & $0.04 \pm 0.01^{\mathrm{a}}$ & $0.02 \pm 0.00^{\mathrm{a}}$ & $1.51 \pm 0.01^{b}$ & $0.07 \pm 0.00^{b}$ & $0.09 \pm 0.00^{b}$ & $0.75 \pm 0.01^{\mathrm{ab}}$ \\
\hline 72 & $0.01 \pm 0.00^{b}$ & $0.01 \pm 0.00^{b}$ & $1.43 \pm 0.04^{b}$ & $0.04 \pm 0.01 \mathrm{ab}$ & $0.02 \pm 0.00 \mathrm{bc}$ & $1.59 \pm 0.01^{a}$ & $0.05 \pm 0.00^{c}$ & $0.07 \pm 0.00^{\mathrm{c}}$ & $0.71 \pm 0.01 b c$ \\
\hline
\end{tabular}


As derived from the results, the values of SCF for Phenanthrene and Pyrene compounds were higher when compared with Benzo[a] Pyrene compound. Moreover, the levels of the Phenanthrene and Pyrene compounds in the shoot and root of Phragmites were greater than those in Vetiver plants. In contrast, the concentration of Benzo[a]Pyrene in the Vetiver was higher than that in the Phragmites. Differences in the biomass of the shoot and root system among plant cultivars are potential reasons for the variation in SCF and RCF, which have a direct contribution to PAHs degradation, as reported Huang et al. [59].

The translocation factor (TF) is used to analyze the ability of plants to transport PAHs from the root to shoot system of plants. The TF values for three PAHs in all treatments were higher than 1 , except B[a]P in Vetiver, as i was less than 1 . Higher values of TF indicate better translocation capacity of PAHs from the roots to shoot tissues. Sun et al. [20] also noted that the TF was used to evaluate the effectiveness of a plant in transferring a chemical from soil to roots and from roots to plant parts. The values of Phenanthrene in both species (Phragmites and Vetiver) were compared with the other two compounds, and it was found that it had gradually increased with the retention time in Phragmites, while it cautiously decreased with the retention time in Vetiver, which was found to be 1.19-1.50 and 1.43-1.70, respectively. The TF value of Pyrene in both plants declined with increasing retention time and found to be in both plants, $1.16-1.25$ and 1.35-1.59, respectively. It was observed that the RCF of Phenanthrene was much higher than that of Pyrene; RCF for Phenanthrene uptake by ryegrass was greatly smaller than RCF for Pyrene uptake. The higher $\mathrm{K}_{\text {ow }}$ value of Pyrene than that of Phenanthrene could be on account of the observed results [30].

TF values for Benzo[a]Pyrene varied between plants, where values slowly decreased over time in Phragmites, from 1.73 to 1.23 , while in Vetiver, TF was $<1.0$ and increased significantly, from 0.65 to 0.71 . A similar trend was observed by Sun et al. [20], as they found that the value of TF in most treatments was less than 1.0. Low TFs indicated that T. patula and M. jalapa took up B[a]P from the soil and transferred it to the aboveground parts, with lower efficiency with increasing time. The difference in variation trends between the three PAHs compounds may be attributed to the physical and chemical properties of these compounds [60].

\subsection{Impact of Lipid Content on PAHs Accumulation}

The results of the correlation between three PAHs compounds and lipid content in Phragmites and Vetiver plants are shown in Figure 9. Schober et al. explain the correlation coefficients are translated into descriptors. A correlation between two variables is considered negligible if the absolute value of the correlation is between 0 and 0.10 ; weak correlation ranges between 0.10 and 0.39 ; moderate correlation is between 0.40 and 0.69 ; strong correlation is between 0.70 and 0.89 ; and very strong correlation is between 0.90 and 1.0 [61]. The different lipid content of plant tissue may influence the PAHs distribution between plant tissues after uptake by the plant. The correlation coefficient between Phenanthrene concentration and lipid content was strong when Phragmites was used with $r^{2}=0.7595$. Meanwhile, the same compound had a moderate correlation coefficient with lipid content in Vetiver with $r^{2}=0.5839$. For hydrophobic substances, such as PAHs, the root uptake is evident and is in a strong correlation with the root lipid content [62].

The correlation between the concentration of Pyrene and the lipid content in Phragmites was strong with $r^{2}=0.7429$, and when the Vetiver was used, it had a moderate correlation with $r^{2}=0.5503$. The amount of uptake depended primarily on the lipid content of plant roots, in which protein, fats, nucleic acids, cellulose tissues, and other components all contain lipophilic components, which appear to be the primary domains where PAHs will accumulate once they penetrate plant root cells [55].

On the other hand, the correlation between Benzo[a]Pyrene concentration and lipid content for Phragmites plants was found to be strong with $r^{2}=0.7108$, while the same correlation was moderate for Vetiver with $r^{2}=0.6248$. Significant correlations between the PAH content and content of lipids were found only during the phase of full plant maturity [63]. 
Plant composition, in particular, lipid content affects the absorption of organic contaminants [30,64]. Based from a study by Gao et al. [65], the accumulation of PAHs in plant tissues, with range associated with plant fat content, had significant associations between Phenanthrene and Pyrene concentrations and lipid contents in the root. The limited PAHs uptake by roots of the plant was affected by the lipid contents. Lin et al. [66] showed how the plant lipid content was useful in predicting the accumulation of PAHs. The variation and accumulation of PAHs in plants may also be observed by the difference in plant lipid content when Phragmites and Vetiver plant species are used in CW. The accumulation of PAHs depends mainly on the plant lipid content, which was found to vary among plant species used in the CWs [55].

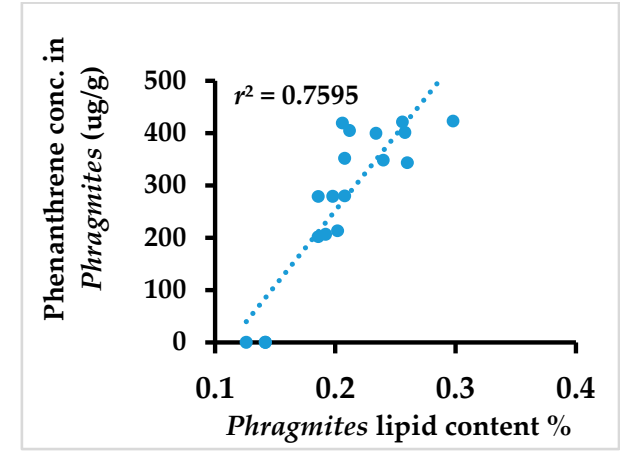

(a)

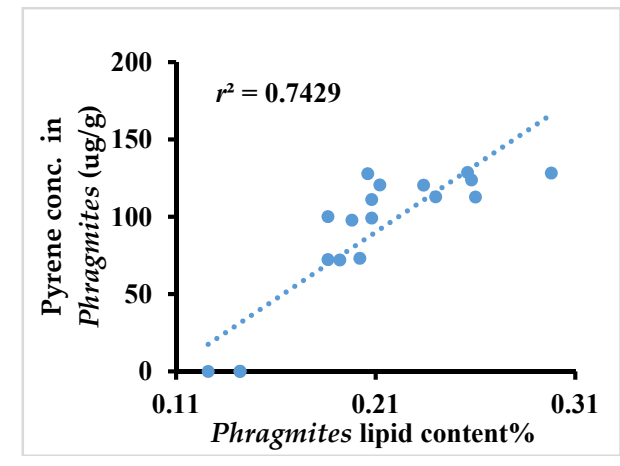

(c)

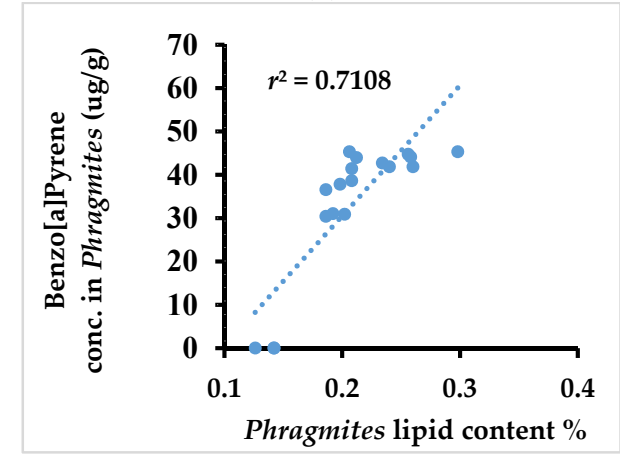

(e)

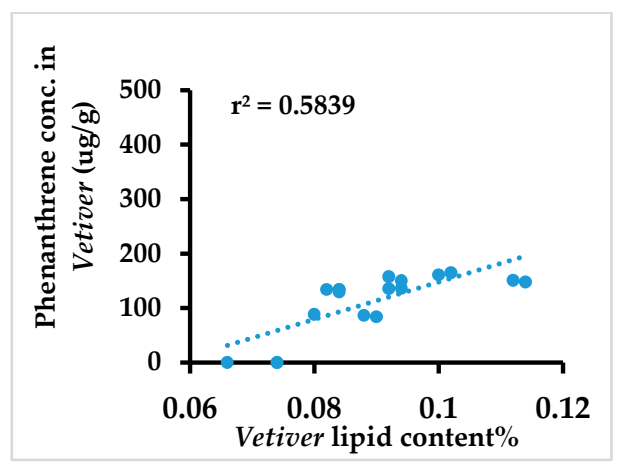

(b)

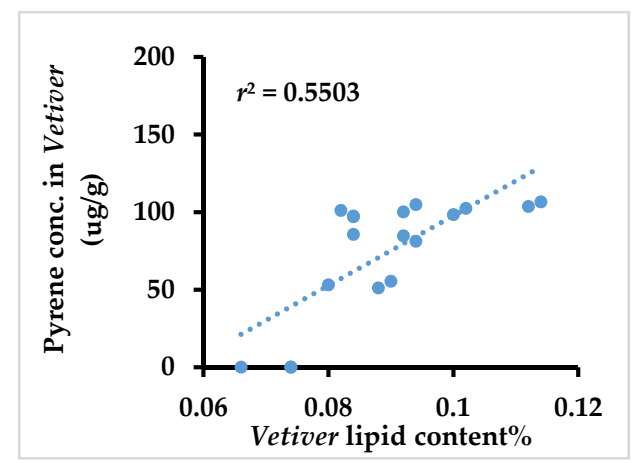

(d)

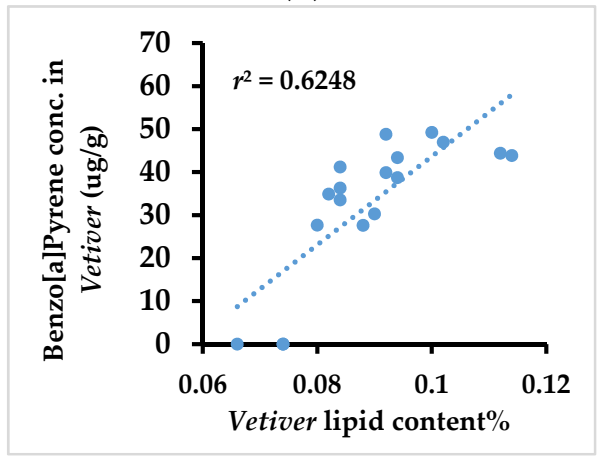

(f)

Figure 9. Correlation between three compounds of PAHs and lipid content. (a) Phenanthrene and lipid content in Phragmites; (b) Phenanthrene and lipid content in Vetiver; (c) Pyrene and lipid content in Phragmites; (d) Pyrene and lipid content in Vetiver; (e) Benzo[a]Pyrene and lipid content in Phragmites; and (f) Benzo[a]Pyrene and lipid content in Vetiver. 


\section{Conclusions}

This study investigated the effectiveness of constructed wetland $(\mathrm{CW})$ in removing harmful pollutants such as PAHs compounds from industrial wastewater. A total of 20 wetland models were used in the investigation. The models were planted with Phragmites and Vetiver plant species in order to access their role in removing PAHs compounds from the industrial wastewater. Synthetic wastewater was prepared for this purpose. Hence, the main conclusions of this study can be summarized as follows. The comparison between unplanted wetland and planted wetland revealed the important role of Phragmites and Vetiver plants in removing PAHs compounds from the industrial wastewater. The maximum difference in removal rates between planted constructed wetland and unplanted constructed wetland was found to be $21 \%$ Phenanthrene, $13 \%$ Pyrene, and 30\% Benzo[a]Pyrene, confirming the role of vegetation in removing pollutants from wastewater in constructed wetlands. A linear relationship was observed between the concentrations of PAHs compounds and lipid content in the Phragmites and Vetiver plants used in CWs. The general relationship can be given as $\mathrm{y}=\mathrm{a}+\mathrm{bx}$, where " $y$ " is the concentration of PAHs compound and " $x$ " is the lipid content; " $a$ " is the intercept on the axis of PAHs compounds concentrations, and " $\mathrm{b}$ " is the slope of the line. The system of the unplanted constructed wetland has the acceptable ability in removing PAHs compounds from wastewater where the removal rate is mainly dependent on the type of PAHs compound. The average percentage removals of PAHs compounds (Phenanthrene, Pyrene, and Benzo[a]Pyrene) by unplanted CWs were found to be $62 \%, 58 \%$, and $55 \%$, respectively.

Author Contributions: Conceptualization, R.A., A.S. and T.M.; methodology, R.A.; validation, A.S., A.I. and T.M.; formal analysis, R.A.; investigation, R.A.; resources, A.S.; data curation, R.A.; writing-original draft preparation, R.A.; writing-review and editing, A.S.; visualization, T.M. and C.F.I.; supervision, A.S., A.I., T.M. and C.F.I.; project administration, A.S.; funding acquisition, A.S. All authors have read and agree to the published version of the manuscript.

Funding: This research was funded by the Universiti Putra Malaysia, grant number GP-IPS/2016/9502900 and the APC was funded by the Universiti Putra Malaysia.

Acknowledgments: The authors acknowledge the financial support by the Universiti Putra Malaysia (GP-IPS/2-16/9502900) and the technical support by the Department of Chemical and Environmental Engineering.

Conflicts of Interest: The authors declare no conflict of interest. The funders had no role in the design of the study; in the collection, analyses, or interpretation of data; in the writing of the manuscript, or in the decision to publish the results.

\section{References}

1. Dsikowitzky, L.; Nordhaus, I.; Jennerjahn, T.C.; Khrycheva, P.; Sivatharshan, Y.; Yuwono, E.; Schwarzbauer, J. Anthropogenic organic contaminants in water, sediments and benthic organisms of the mangrove-fringed Segara Anakan Lagoon, Java, Indonesia. Mar. Pollut. Bull. 2011, 62, 851-862. [CrossRef]

2. Muff, J.; Sogaard, E.G. Electrochemical degradation of PAH compounds in process water: A kinetic study on model solutions and a proof of concept study on runoff water from harbour sediment purification. Water Sci. Technol. 2010, 61, 2043-2051. [CrossRef]

3. Al-Sbani, N.H.; Abdullah, S.R.S.; Idris, M.; Hasan, H.A.; Jehawi, O.H.; Ismail, N.I. Sub-surface flow system for PAHs removal in water using Lepironia articulate under greenhouse conditions. Ecol. Eng. 2016, 87, 1-8. [CrossRef]

4. Chen, Z.; Wu, S.; Braeckevelt, M.; Paschke, H.; Kastner, M.; Koser, H.; Kuschk, P. Effect of vegetation in pilot-scale horizontal subsurface flow constructed wetlands treating sulphate rich groundwater contaminated with a low and high chlorinated hydrocarbon. Chemosphere 2012, 89, 724-731. [CrossRef]

5. Mahmoud, A.E.D.; Fawzy, M. Bio-Based Methods for Wastewater Treatment: Green Sorbents. In Phytoremediation, 1st ed.; Ansari, A.A., Gill, S.S., Gill, R., Lanza, G.R., Newman, L., Eds.; Springer: Berlin/Heidelberg, Germany, 2016.

6. Chen, Y.; Wen, Y.; Zhou, Q.; Vymazal, J. Effects of plant biomass on denitrifying genes in subsurface-flow constructed wetlands. Bioresour. Technol. 2014, 157, 341-345. [CrossRef] 
7. Leto, C.; Tuttolomondo, T.; La Bella, S.; Leone, R.; Licata, M. Effects of plant species in a horizontal subsurface flow constructed wetland-Phytoremediation of treated urban wastewater with Cyperus alternifolius L. and Typha latifolia L. in the West of Sicily (Italy). Ecol. Eng. 2013, 61, 282-291. [CrossRef]

8. Türker, O.C.; Türe, C.; Böcük, H.; Çiçek, A.; Yakar, A. Role of plants and vegetation structure on boron (B) removal process in constructed wetlands. Ecol. Eng. 2016, 88, 143-152. [CrossRef]

9. Fountoulakis, M.S.; Terzakis, S.; Kalogerakis, N.; Manios, T. Removal of polycyclic aromatic hydrocarbons and linear alkylbenzene sulfonates from domestic wastewater in pilot constructed wetlands and a gravel filter. Ecol. Eng. 2009, 35, 1702-1709. [CrossRef]

10. Rasmussen, G.; Olsen, R.A. Sorption and biological removal of creosote-contaminants from groundwater in soil/sand vegetated with orchard grass (Dactylis glomerata). Adv. Environ. Res. 2004, 8, 313-327. [CrossRef]

11. Huesemann, M.H.; Hausmann, T.S.; Fortman, T.J.; Thom, R.M.; Cullinan, V. In situ phytoremediation of PAHand PCB-contaminated marine sediments with eelgrass (Zostera marina). Ecol. Eng. 2009, 35, 1395-1404. [CrossRef]

12. Newman, L.A.; Reynolds, C.M. Phytodegradation of organic compounds. Environ. Biotechnol. 2004, 15, 225-230. [CrossRef] [PubMed]

13. Cui, Y.; Zhang, W.; Sun, H.; Wu, W.-M.; Zou, X. Polycyclic Aromatic Hydrocarbon Accumulation in Phragmites australis Grown on Constructed Wetland for Sludge Stabilization. J. Residuals Sci. Technol. 2015, 12, 215-220. [CrossRef]

14. Lu, M.; Gu, L.P.; Xu, W.H. Treatment of petroleum refinery wastewater using a sequential anaerobic-aerobic moving-bed biofilm reactor system based on suspended ceramsite. Water Sci. Technol. 2013, 67, 1976-1983. [CrossRef] [PubMed]

15. Sponza, D.T.; Gok, O. Effect of rhamnolipid on the aerobic removal of polyaromatic hydrocarbons (PAHs) and COD components from petrochemical wastewater. Bioresour. Technol. 2010, 101, 914-924. [CrossRef] [PubMed]

16. Mahmoud, A.E.; Fawzy, M.; Radwan, A. Optimization of Cadmium $\left(\mathrm{CD}^{2+}\right)$ removal from aqueous solutions by novel biosorbent. Int. J. phytoremediat. 2016, 18, 619-625. [CrossRef]

17. Hadad, H.R.; Maine, M.A.; Bonetto, C.A. Macrophyte growth in a pilot-scale constructed wetland for industrial wastewater treatment. J. Chemosphere 2006, 63, 1744-1753. [CrossRef]

18. Tuncel, S.G.; Topal, T. Multifactorial Optimization Approach for Determination of Polycyclic Aromatic Hydrocarbons in Sea Sediments of Turkish Mediterranean Coast. Am. J. Anal. Chem. 2011, 2, 783-794. [CrossRef]

19. Zhu, L.; Zhang, M. Effect of rhamnolipids on the uptake of PAHs by ryegrass. Environ. Pollut. 2008, 156, 46-52. [CrossRef]

20. Sun, Y.; Zhou, Q.; Xu, Y.; Wang, L.; Liang, X. Phytoremediation for co-contaminated soils of benzo[a]pyrene $(\mathrm{B}[\mathrm{a}] \mathrm{P})$ and heavy metals using ornamental plant Tagetes patula. J. Hazard. Mater. 2011, 186, 2075-2082. [CrossRef]

21. Hübner, T.M.; Tischer, S.; Tanneberg, H.; Kuschk, P. Influence of Phenol and Phenanthrene on the Growth of Phalaris arundinacea and Phragmites australis. Int. J. Phytoremediat. 2000, 2, 331-342. [CrossRef]

22. Xia, H.P. Ecological rehabilitation and phytoremediation with four grasses in oil shale mined land. Chemosphere 2004, 54, 345-353. [CrossRef]

23. Wang, J.; Liu, X.; Zhang, X.; Liang, X.; Zhang, W. Growth Response and Phytoremediation Ability of Reed for Diesel Contaminant. Procedia Environ. Sci. 2011, 8, 68-74. [CrossRef]

24. Afegbua, S.L.; Batty, L.C. Effect of single and mixed polycyclic aromatic hydrocarbon contamination on plant biomass yield and PAH dissipation during phytoremediation. Environ. Sci. Pollut. Res. 2018, 25, 18596-18603. [CrossRef]

25. Kang, Y.; Xie, H.; Li, B.; Zhang, J.; Hao Ngo, H.; Guo, W.; Guo, Z.; Kong, Q.; Liang, S.; Liu, J.; et al. Performance of constructed wetlands and associated mechanisms of PAHs removal with mussels. Chem. Eng. J. 2019, 357, 280-287. [CrossRef]

26. Andreote, F.D.; Rocha, U.N.; Araujo, W.L.; Azevedo, J.L.; van Overbeek, L.S. Effect of bacterial inoculation, plant genotype and developmental stage on root-associated and endophytic bacterial communities in potato (Solanum tuberosum). Antonie van Leeuwenhoek 2010, 97, 389-399. [CrossRef]

27. Yergeau, E.; Sanschagrin, S.; Maynard, C.; St-Arnaud, M.; Greer, C.W. Microbial expression profiles in the rhizosphere of willows depend on soil contamination. Int. Soc. Microb. Ecol. J. 2014, 8, 344-358. [CrossRef] 
28. Andreolli, M.; Lampis, S.; Poli, M.; Gullner, G.; Biro, B.; Vallini, G. Endophytic Burkholderia fungorum DBT1 can improve phytoremediation efficiency of polycyclic aromatic hydrocarbons. Chemosphere 2013, 92, 688-694. [CrossRef]

29. Sun, Y.; Zhou, Q. Uptake and translocation of benzo[a]pyrene (B[a]P) in two ornamental plants and dissipation in soil. Ecotoxicol. Environ. Saf. 2016, 124, 74-81. [CrossRef]

30. Gao, Y.; Ling, W. Comparison for plant uptake of phenanthrene and pyrene from soil and water. Biol. Fertil. Soils 2006, 42, 387-394. [CrossRef]

31. Chiapusio, G.; Pujol, S.; Toussaint, M.L.; Badot, P.M.; Binet, P. Phenanthrene toxicity and dissipation in rhizosphere of grassland plants (Lolium perenne L. and Trifolium pratense L.) in three spiked soils. Plant Soil 2007, 294, 103-112. [CrossRef]

32. Wang, Z.; Liu, Z.; Yang, Y.; Li, T.; Liu, M. Distribution of PAHs in tissues of wetland plants and the surrounding sediments in the Chongming wetland, Shanghai, China. Chemosphere 2012, 89, 221-227. [CrossRef] [PubMed]

33. Chevron Cottin, N.; Merlin, G. Study of pyrene biodegradation capacity in two types of solid media. Sci. Total Environ. 2007, 380, 116-123. [CrossRef] [PubMed]

34. Pan, W.; Wu, C.; Wang, Q.; Su, Z.; Zhou, H.; Chung AK, C.; Hartley, W.; Ge, L. Effect of wetland plants and bacterial inoculation on dissipation of phenanthrene. Int. J. Phytoremediat. 2017, 19, 870-876. [CrossRef] [PubMed]

35. Gao, Y.; Li, Q.; Ling, W.; Zhu, X. Arbuscular mycorrhizal phytoremediation of soils contaminated with phenanthrene and pyrene. J. Hazard. Mater. 2011, 185, 703-709. [CrossRef] [PubMed]

36. Warężak, T.; Włodarczyk-Makuła, M.; Sadecka, Z. Accumulation of PAHs in plants from vertical flow-constructed wetland. Desalin. Water Treat. 2015, 57, 1273-1285. [CrossRef]

37. Sieciechowicz, A.; Sadecka, Z.; Myszograj, S.; Włodarczyk-Makuła, M.; Wiśniowska, E.; Turek, A. Occurrence of heavy metals and PAHs in soil and plants after application of sewage sludge to soil. Desalin. Water Treat. 2014, 52, 4014-4026. [CrossRef]

38. Haritash, A.K.; Kaushik, C.P. Biodegradation aspects of polycyclic aromatic hydrocarbons (PAHs): A review. J. Hazard. Mater. 2009, 169, 1-15. [CrossRef]

39. Dugaya, A.; Czokc, C.H.M.; Guyona, F.; Pagesd, N. New procedure for selective extraction of polycyclic aromatic hydrocarbons in plants for gas chromatographic-mass spectrometric analysis. J. Chromatogr. A 2002, 958, 1-7. [CrossRef]

40. Abid, A.A.; Sarvajeet, S.G.R.G.; Guy, R.L.; Lee, N. Phytoremediation Management of Environmental Contaminants; Springer: Berlin/Heidelberg, Germany, 2016.

41. Braeckevelt, M.; Reiche, N.; Trapp, S.; Wiessner, A.; Paschke, H.; Kuschk, P.; Kaestner, M. Chlorobenzene removal efficiencies and removal processes in a pilot-scale constructed wetland treating contaminated groundwater. Ecol. Eng. 2011, 37, 903-913. [CrossRef]

42. Soleimani, M.; Afyuni, M.; Hajabbasi, M.A.; Nourbakhsh, F.; Sabzalian, M.R.; Christensen, J.H. Phytoremediation of an aged petroleum contaminated soil using endophyte infected and non-infected grasses. Chemosphere 2010, 81, 1084-1090. [CrossRef]

43. Tee, H.C.; Lim, P.E.; Seng, C.E.; Nawi, M.A. Newly developed baffled subsurface-flow constructed wetland for the enhancement of nitrogen removal. Bioresour. Technol. 2012, 104, 235-242. [CrossRef] [PubMed]

44. Terzakis, S.; Fountoulakis, M.S.; Georgaki, I.; Albantakis, D.; Sabathianakis, I.; Karathanasis, A.D.; Kalogerakis, N.; Manios, T. Constructed wetlands treating highway runoff in the central Mediterranean region. Chemosphere 2008, 72, 141-149. [CrossRef] [PubMed]

45. Machate, T.; Behrens, H.A.; Kettrup, A. Degrdation of Phenanthrene and hydraulic characteristics in a constructed wetland. Water Res. 1997, 31, 554-560. [CrossRef]

46. Fraser, L.H.; Carty, S.M.; Steer, D. A test of four plant species to reduce total nitrogen and total phosphorus from soil leachate in subsurface wetland microcosms. Bioresour. Technol. 2004, 94, 185-192. [CrossRef] [PubMed]

47. Huang, X.; Zheng, J.; Liu, C.; Liu, L.; Liu, Y.; Fan, H. Removal of antibiotics and resistance genes from swine wastewater using vertical flow constructed wetlands: Effect of hydraulic flow direction and substrate type. Chem. Eng. J. 2017, 308, 692-699. [CrossRef]

48. Ballesteros, F.; Vuong, T.H.; Secondes, M.F.; Tuan, P.D. Removal efficiencies of constructed wetland and efficacy of plant on treating benzene. Sustain. Environ. Res. 2016, 26, 93-96. [CrossRef] 
49. Zhang, H. PAH Degradation in Wetland Soils as Influenced by Redox Potential. Available online: https: //digitalcommons.lsu.edu/gradschool_theses/374 (accessed on 12 August 2019).

50. Suresh, B.; Ravishankar, G.A. Phytoremediation-A novel and promising approach for environmental clean-up. Biotechnology 2004, 24, 97-124. [CrossRef]

51. Yu, X.Z.; Wu, S.C.; Wu, F.Y.; Wong, M.H. Enhanced dissipation of PAHs from soil using mycorrhizal ryegrass and PAH-degrading bacteria. J. Hazard. Mater. 2011, 186, 1206-1217. [CrossRef]

52. Prachy Dixit, P.K.M.; Pramod, D.; Sherkhane Sharad, P. Kale, Susan Eapen*, Enhanced tolerance and remediation of anthracene by transgenic tobacco plants expressing a fungal glutathione transferase gene. J. Hazard. Mater. 2011, 192, 270-276. [CrossRef]

53. Wang, H.-Y.; Huang, H.-F.; Jiang, J.-Q. The effect of metal cations on phenol adsorption by hexadecyltrimethyl-ammonium bromide (hdtma) modified clinoptilolite (Ct.). Sep. Purif. Technol. 2011, 80, 658-662. [CrossRef]

54. Garcia-Sanchez, M.; Kosnar, Z.; Mercl, F.; Aranda, E.; Tlustos, P. A comparative study to evaluate natural attenuation, mycoaugmentation, phytoremediation, and microbial-assisted phytoremediation strategies for the bioremediation of an aged PAH-polluted soil. Ecotoxicol. Environ. Saf. 2018, 147, 165-174. [CrossRef] [PubMed]

55. Gao, Y.; Zhu, L. Plant uptake, accumulation and translocation of phenanthrene and pyrene in soils. Chemosphere 2004, 55, 1169-1178. [CrossRef] [PubMed]

56. Cottin, N.; Merlin, G. Removal of PAHs from laboratory columns simulating the humus upper layer of vertical flow constructed wetlands. Chemosphere 2008, 73, 711-716. [CrossRef] [PubMed]

57. Liu, H.; Weisman, D.; Ye, Y.-B.; Cui, B.; Huang, Y.-H.; Colón-Carmona, A.; Wang, Z.-H. An oxidative stress response to polycyclic aromatic hydrocarbon exposure is rapid and complex in Arabidopsis thaliana. Plant Sci. 2009, 176, 375-382. [CrossRef]

58. Sivaram, A.K.; Logeshwaran, P.; Subashchandrabose, S.R.; Lockington, R.; Naidu, R.; Megharaj, M. Comparison of plants with C3 and C4 carbon fixation pathways for remediation of polycyclic aromatic hydrocarbon contaminated soils. Sci. Rep. 2018, 8, 2100. [CrossRef]

59. Huang, L.; Chernyak, S.M.; Batterman, S.A. PAHs (polycyclic aromatic hydrocarbons), nitro-PAHs, and hopane and sterane biomarkers in sediments of southern Lake Michigan, USA. Sci. Total Environ. 2014, 487, 173-186. [CrossRef] [PubMed]

60. Yang, B.; Liu, S.; Liu, Y.; Li, X.; Lin, X.; Liu, M.; Liu, X. PAHs uptake and translocation in Cinnamomum camphora leaves from Shanghai, China. Sci. Total Environ. 2017, 574, 358-368. [CrossRef]

61. Schober, P.; Boer, C.; Schwarte, L.A. Correlation coefficients: Appropriate use and interpretation. Anesth. Analg. 2018, 126, 1763-1768. [CrossRef]

62. Reichenauer, T.G.; Germida, J.J. Phytoremediation of organic contaminants in soil and groundwater. Chem. Sustain. 2008, 1, 708-717. [CrossRef]

63. Alagić, S.Č.; Maluckov, B.S.; Radojičić, V.B. How can plants manage polycyclic aromatic hydrocarbons? May these effects represent a useful tool for an effective soil remediation? A review. Clean Technol. Environ. Policy 2014, 17, 597-614. [CrossRef]

64. Chiou, S. Manes A Partition-Limited Model for the Plant Uptake of Organic Contaminants from Soil and Water. Sci. Total Environ. 2001, 35, 1437-1444. [CrossRef] [PubMed]

65. Gao, Y.; Zhu, L.; Ling, W. Application of the partition-limited model for plant uptake of organic chemicals from soil and water. Sci. Total Environ. 2005, 336, 171-182. [CrossRef] [PubMed]

66. Lin, H.; Tao, S.; Zuo, Q.; Coveney, R.M. Uptake of polycyclic aromatic hydrocarbons by maize plants. Environ. Pollut. 2007, 148, 614-619. [CrossRef] [PubMed]

(C) 2020 by the authors. Licensee MDPI, Basel, Switzerland. This article is an open access article distributed under the terms and conditions of the Creative Commons Attribution (CC BY) license (http://creativecommons.org/licenses/by/4.0/). 